\title{
Eastern Europe still strapped for cash..
}

[MUNICH] None of the central-east European countries that are candidates for membership of the European Union (EU) plans to significantly increase its research spending next year, despite announcements that they would do so in anticipation of joining the EU.

The European Commission is concerned that, unless the governments of Poland, Hungary, the Czech Republic and Slovenia increase their spending soon, they will be badly placed to exploit their new status as full associates of the commission's fifth Framework programme of research (FP5), which will be launched this year.

This status, which allows them to participate in all FP5 programmes in exchange for a financial contribution equivalent to that of EU member states, is intended to help introduce the countries into the culture of the EU.

Along with Estonia and Cyprus, the four countries are currently negotiating EU membership after 2003. But each spends much less on research and development than the EU average of 1.8 per cent of gross domestic product (GDP), equivalent to US $\$ 350$ per capita.

A major criterion for membership is that their economies should be roughly aligned with EU norms, and the commission has been encouraging each candidate to raise its research spending as part of this effort.

"The average expenditure in candidate countries is much lower than that in EU members, although there is some overlap in the ranges of expenditure," says Rainer Gerold, head of the commission's section on research and eastern European countries.

Slovenia, for example, already spends more than some of the poorer member states, which are also a worry to the commission. In 1995, the Slovenian government and industry's combined contributions added up to $\$ 150$ per capita (1.7 per cent of GDP), compared with Greece's $\$ 60$ per capita (0.7 per cent of GDP).

But, in contrast, Poland and Hungary spent only $\$ 21$ (0.7 per cent of GDP) and \$28 (0.7 per cent of GDP) per capita, respectively, in the same year, and the Czech Republic spent $\$ 50$ per capita ( 1.0 per cent of GDP).

No fixed targets for research expenditure have been defined for the candidates, says Gerold, but discussions have led to governments setting their own goals. According to government statements, Poland, Hungary and the Czech Republic are aiming for public expenditure alone on research of 0.7 per cent of GDP before 2003, and Slovenia is aiming for 1.2 per cent of GDP. Each expects its industry to match public spending.

But scientists in these four countries are sceptical about the seriousness of these intentions, as promises to begin significant spending increases in 1999 have failed to materialize in terms of firm commitments.

Indeed, in Poland a significant cut in spending was avoided only after a dozen or so top scientists formed a group called Save Polish Science and orchestrated a vigorous press campaign against the government's proposed cuts. As a result, public spending on research and development will remain at around 0.45 per cent of GDP next year, where it has stagnated for most of the 1990s.

Hungarian scientists also had to fight to maintain present spending levels. According to Laszlo Keviczky, president of the Hungarian Academy of Sciences, scientists "were lucky to emerge with a steady-state budget which takes into account inflation".

RudolfZahradník, president of the Czech Academy of Sciences, foresees no significant rise in the Czech science budget this year. $\mathrm{He}$ is angry with the government for not giving a clear indication of how the target for the period before EU accession will be reached.

Slovenian scientists fared better. "With a seven per cent rise in $\mathrm{R} \& \mathrm{D}$ budget in real terms, we cannot complain so much," says Venčeslav Kaučič, head of inorganic chemistry at the National Institute of Chemistry in Ljubljana. But he points out that the past three years have seen a significant decline in government spending on research from 0.8 per cent of GDP to around 0.7 per cent. Spending power has remained roughly constant because of the growth in GDP.

Although promises for increased funding in 1999 have been broken, the next set of promises is already being made. Poland's vicepresident Pavel Merdlyk, who chairs the government's science and technology advisory committee, announced last month that "sub- stantial increases would start in 2000 or 2001 ".

Candidate countries began negotiating the details of their full associate membership of FP5 last October. In order to help them readjust their overall finances, they will be offered decreasing annual discounts on their contributions to the FP5 budget, with the full contributions being payable in 2002.

European Commission officials admit they are worried that, if countries do not increase spending on domestic research and development soon, they will find difficulties meeting the later FP5 payments.

Lack of research investment is also threatening the future of research in these countries by keeping salaries in the public sector low, and by limiting the amount of internationally competitive work that is possible.

Andrej Wroblewski, a professor of physics at Warsaw University and a member of Save Polish Science, says that the situation for scientists in Poland is "desperate". "Science is collapsing here," he says, pointing to a dearth of PhD students - the number has fallen to its level 30 years ago - and a slow erosion of Poland's position in the world's publication ranking list.

The prospect of higher financial rewards is turning the smartest graduates away from research and towards sectors such as commerce and banking. "This internal braindrain is robbing our countries of our next generation of scientists," says Wroblewski.

An external brain-drain is also causing problems. A recent evaluation of Hungarian biology by the European Molecular Biology Organization (see below) concluded that low salaries are still driving the best scientists to emigrate.

Alison Abbott

\section{...but much Hungarian biology is world class}

[MUNIOH] Biological research at institutes of the Hungarian Academy of Sciences is generally of a "high standard", and one-third of the research groups are of international standard, according to an international evaluation committee.

But the committee, which was chaired by Kai Simons, head of cell biology at the European Molecular Biology Laboratory, warns the Hungarian government that standards will collapse if investment in research continues at a low level.

The evaluation was requested by the academy last year and organized by the European Molecular Biology Organization. The committee of 12 scientists from around Europe judged 16 out of the 46 groups it assessed - predominantly in plant biology and developmental genetics - to be "world class".

The committee said this was a remarkable achievement given the low level of funding. But it warned that "it will not be possible to maintain this level of excellence in the future if funding is not increased".

"There are already some visible signs of deterioration which do not bode well for the future," it said. The panel found that the best scientists are still going abroad, leaving behind a lack of potential young group leaders, while the standard of equipment is generally low.

The two most urgent problems, it said, are the very low wages and the small size of the average research grant. With salaries ranging from US $\$ 240$ to $\$ 660$ per month, most researchers have to take second jobs.

The committee recommends that the government establishes a programme of generous grants to allow young researchers to work to international standards. 